\title{
Inhibitory effects of Camellia japonica on cell inflammation and acute rat reflux esophagitis
}

\author{
Hyeon Hwa Nam', Li Nan² and Byung Kil Choo ${ }^{3 *}$ (D)
}

\begin{abstract}
Background: Excessive and continuous inflammation may be the main cause of various immune system diseases. Reflux esophagitis (RE) is a common gastroesophageal reflux disease (GERD). Camellia japonica has high medicinal value and has long been used as a traditional herbal hemostatic medicine in China and Korea. The purpose of this study is to explore the antioxidant and anti-inflammatory activities of CJE and its protective effect on RE.

Materials and methods: Buds from C. japonica plants were collected in the mountain area of Jeju, South Korea. Dried C. japonica buds were extracted with 75\% ethanol. DPPH and ABTS radical scavenging assay were evaluated according to previous method. The ROS production and anti-inflammatory effects of $C$. japonica buds ethanol extract (CJE) were evaluated on LPS-induced RAW 264.7 cell inflammation. The protective effects of CJE on RE were conducted in a RE rat model.

Results: CJE eliminated over $50 \%$ of DPPH and ABTS radical at concentration of 100 and $200 \mu \mathrm{g} / \mathrm{mL}$, respectively. CJE alleviated changes in cell morphology, reduced production of ROS, NO and IL-1 $\beta$. Also, down-regulated expression levels of iNOS, TNF-a, phosphorylated NF-KB, IKBa, and JNK/p38/MAPK. CJE reduced esophageal tissue damage ratio (40.3\%) and attenuation of histological changes. In addition, CJE down-regulated the expression levels of TNF- $a$, IL-1 $\beta$, COX-2 and phosphorylation levels of NF-kB and IkBa in esophageal tissue.
\end{abstract}

Conclusions: CJE possesses good anti-oxidation and anti-inflammatory activity, and can improve RE in rats caused by gastric acid reflux. Therefore, CJE is a natural material with good anti-oxidant and anti-inflammatory activity and has the possibility of being a candidate phytomedicine source for the treatment of RE.

Keywords: Anti-oxidant, Anti-inflammation, Cytokines, Camellia japonica, Reflux esophagitis, NF-kB/MAPK signaling pathway

\section{Background}

Inflammation is a defensive response that occurs when the host is exposed to external stimuli. The main symptoms are redness, swelling, and fever. Through this defense response, the host can heal itself and maintain the normal function of the body [1]. However, excessive and continuous inflammation may be the main cause of various immune system diseases including diabetes,

\footnotetext{
*Correspondence: bkchoo@jbnu.ac.kr

${ }^{3}$ Department of Crop Science \& Biotechnology, Chonbuk National University, 54896 Jeonju, Republic of Korea

Full list of author information is available at the end of the article
}

rheumatoid arthritis, neurodegenerative diseases, and even cancer [2]. Reactive oxygen species (ROS) is a byproduct produced by incomplete reduction of oxygen molecules during respiration. Excessive generation of ROS in the body will disrupt the body's redox balance, which is one of the causes of inflammation [3]. Immune cells such as lymphocytes and macrophages are the main cells that maintain stability of the host and react to infection by enhancing the immune response. When external stimuli (endotoxins and microorganisms) break through the body's physical barriers, Toll-like receptors (TLR) in these cells can recognize them and activate the body to produce immune cell responses [4]. They produce 
and secrete inflammatory mediators (nitrite oxide), inflammatory cytokines (TNF- $\alpha$ and interleutin-1 $\beta$ ) and proteins (inducible nitric oxide synthase and cyclooxygenase-2) to play a key role in the occurrence and development of inflammation [5]. According to previous studies, the cellular inflammation model induced by lipopolysaccharide (LPS), a constituent of the cell wall of Gram-negative bacteria, has been widely used in the study of the anti-inflammatory effects of active substances such as plant extracts and compounds [6].

Reflux esophagitis (RE), a common gastroesophageal reflux disease (GERD), is inflammation of the esophagus caused by reflux of gastric contents to the esophagus due to dysfunction of the lower esophageal sphincter [7]. $\mathrm{RE}$ is showing a continuous upward trend worldwide. As stomach contents are mainly composed of gastric acid, frequent reflux can cause ulceration of the esophageal epithelial tissue and even esophageal cancer [8]. Currently, the most effective drugs are mainly gastric acid secretion inhibitors including $\mathrm{H}_{2}$ receptor antagonist (ranitidine) and proton pump inhibitors (PPI, omeprazole), although these drugs have good therapeutic efficacy, long-term use may cause side effects like intestinal infection [9]. Therefore, it is a problem that needs to be solved urgently to search for natural phamaceutical materials for treating RE with good therapeutic effects and limited side effects.

Camellia japonica L. (Theaceae), also called Japanese camellia, is native to China and Japan [10]. As an ornamental plant, $C$. japonica is often planted in courtyards and roadsides. $C$. japonica has high medicinal value and has long been used as a traditional herbal hemostatic medicine in China and Korea [11]. A lot of previous studies have demonstrated the various biological activities of extracts from parts of $C$. japonica. The leaf extract of was shown to promote anti-oxidative protein expression and suppress apoptosis in human corneal epithelial cells [12]. Antioxidant properties of the flower ethanol extract were also investigated in human $\mathrm{HaCaT}$ cells, and the anti-atherogenic effects of the fruit extract were confirmed in rats fed a high-fat diet [13, 14]. However, systematic research on the antioxidant and anti-inflammatory activities of $C$. japonica buds is still inadequate. In addition, research on its protective effect on RE in rats also has never been conducted.

In the present study, to determine the activity of $C$. japonica buds $70 \%$ ethanol extract (CJE), we measured its antioxidant effect by determining DPPH and ABTS free radical scavenging activities and measured its antiinflammatory effect using LPS-induced RAW 264.7 cells inflammatory model. Furthermore, to explore the protective effect of CJE on RE, we used rat RE model by observing esophageal tissue damage ratio, esophageal histological study and inflammatory protein expression level Our results show that CJE possesses excellent antioxidant and anti-inflammatory activity and improves rat's esophageal tissue damage in RE rats. Therefore, we believe that CJE is a natural material with good physiological activity and could be a candidate phytomedicine source for treating RE.

\section{Materials and methods \\ Reagents and antibodies}

LPS, HEPE, ranitidine hydrochloride, protease inhibitor cocktail, DCFH-DA and DMSO were purchased from Sigma (St. Louis, MO, USA). The cell viability, proliferation, and cytotoxicity assay kits were purchased from DoGenBio Co., Ltd (Guro-gu, Seoul, South Korea). DMEM, FBS, and penicillin and streptomycin were purchased from Welgene (Namcheon-ro, South Korea). Griess reagent was purchased from Promega (Fithchburg, WI, USA). DAPI (Sigma-Aldrich, St.Louis, MO, USA). DC ${ }^{\mathrm{TM}}$ Protein assay reagent, polyvinylidene fluoride membranes, and bovine serum albumin standard were purchased from Bio-Rad Laboratories (Hercules, CA, USA). The phenylmethylsulfonyl fluoride, and ethylenediaminetetraacetic acid were purchased from Corporation Cleveland (OH, USA). iNOS, COX-2, IL-1 $\beta$, TNF- $\alpha, \beta$-actin antibodies, m-IgGk BP-HRP secondary antibody and Luminol reagent were purchased from Santa Cruz Biotechnology (Delaware Ave, CA, USA). The p-IкB $\alpha$, IкB $\alpha, p-N F-\kappa B$ p65, NF-кB p65, p-SAPK/JNK, SAPK/JNK, p-p38 MAPK, p38 MAPK, p-p44/42 MAPK (Erk1/2), p44/42 MAPK (Erk1/2), and Lamin B1 antibodies were purchased from Cell Signaling Technology (Danvers, MA, USA).

\section{CJE preparation}

Buds from C. japonica plants were collected in the mountain area of Jeju, South Korea, and authenticated by the Korean Institute of Oriental Medicine (KIOM). Dried buds were suspended in 10 volumes of $75 \%$ ethanol and extracted three times for two hours each in a circulation distillation unit at $50{ }^{\circ} \mathrm{C}$. The ethanol extracts were filtered through advance filter paper, freeze-dried, pulverized, and stored at $-80{ }^{\circ} \mathrm{C}$ until use.

\section{DPPH and ABTS radical scavenging assay}

The DPPH radical scavenging assay was conducted using the method of Liyana-Pathirana $\mathrm{C}$ and Shahidi $\mathrm{F}$ [15]. For this, DPPH $(0.2 \mathrm{mM})$ in methanol and different concentrations of CJE $(25,50,100 \mu \mathrm{g} / \mathrm{mL})$ were mixed in a 1:1 ratio. The mixture was incubated at $37^{\circ} \mathrm{C}$ for $30 \mathrm{~min}$, and then the absorbance at $517 \mathrm{~nm}$ was measured using a microplate reader (Multiscan spectrum, Thermo Scientific). 
The ABTS radical scavenging assay was conducted using the method of Jing et al. [16]. Here, ABTS $(0.7 \mathrm{mM})$ and $2.4 \mathrm{mM}$ potassium persulfate $\left(\mathrm{K}_{2} \mathrm{~S}_{2} \mathrm{O}_{8}\right)$ solution were mixed in a 2:1 ratio and reacted at room temperature for $16 \mathrm{~h}$ in the dark. The absorbance of the mixture at $734 \mathrm{~nm}$ was measured using a microplate reader, and the mixture was used when the value was in the range of $0.70 \pm 0.02$. ABTS and different concentrations of CJE $(50,100,200 \mu \mathrm{g} / \mathrm{mL})$ were mixed in a 1:9 ratio. The absorbance at $734 \mathrm{~nm}$ was measured using a microplate reader (Multiscan spectrum, Thermo Scientific).

\section{Cell culture}

RAW264.7 cells were obtained from the American Type Culture Collection and cultured in medium containing DMEM, 10\% FBS, 100 units/mL penicillin, and $100 \mu \mathrm{g} /$ $\mathrm{mL}$ streptomycin. Cells were incubated in a $5 \% \mathrm{CO}_{2}$ and $95 \%$ air environment at $37{ }^{\circ} \mathrm{C}$. The cells were grown to logarithmic phase for the experiments.

\section{Determination of intracellular reactive oxygen species (ROS)}

To measure intracellular ROS content, RAW264.7 cells were plated at a concentration $3 \times 10^{5}$ cells $/ \mathrm{mL}$. CJE at concentrations of $12.5,25$, and $50 \mu \mathrm{g} / \mathrm{mL}$ was added and incubated for $1 \mathrm{~h}$, and LPS $(1 \mu \mathrm{g} / \mathrm{mL})$ was added for cotreatment for another $8 \mathrm{~h}$. Then DCFH-DA $(10 \mathrm{uM})$ solution was added to cells. After $30 \mathrm{~min}$, the fluorescence intensity was measured by multimode microplate reader (Perkin Elmer, Gyeonggi-do, South Korea) at excitation wavelength $485 \mathrm{~nm}$ and emission wavelength $535 \mathrm{~nm}$.

\section{Cell viability and cell morphology observation and quantitation assay}

To determine cell viability, RAW264.7 cells were seeded at a concentration of $5 \times 10^{5}$ cells $/ \mathrm{mL}$ in a 96 -well plate. Cells were pre-treated with CJE at concentrations of 50, 100 , and $200 \mu \mathrm{g} / \mathrm{mL}$ and incubated for $1 \mathrm{~h}$. Then, LPS $(1 \mu \mathrm{g} / \mathrm{mL})$ was added to the plate, and the cells were further incubated for $18 \mathrm{~h}$. Cell viability was measured with the proliferation and cytotoxicity assay kit. Cell morphology was observed by inverted microscope (Nikon, Melville, NY USA) and quantified by the Image J program. The calculation formula was as follows: Roundness factor $(\mathrm{RNF})=\frac{4 A}{\pi \times d_{\max }^{2}}$ (A: cell area, $\mathrm{d}_{\max }$ : maximum diameter).

\section{Nitric oxide assay}

To determine the production of nitrite in culture media, RAW264.7 cells were seeded at a concentration of $5 \times 10^{5}$ cells $/ \mathrm{mL}$ in a 96 -well plate. Cells were pre-treated with CJE at concentrations of 50,100, and $200 \mu \mathrm{g} / \mathrm{mL}$ and incubated for $1 \mathrm{~h}$. Then, LPS $(1 \mu \mathrm{g} / \mathrm{mL})$ was added, and the plate was further incubated for $18 \mathrm{~h}$. Production of nitrite was measured in the Griess reagent according to the manufacturer's instructions. Nitrite concentration was determined at $540 \mathrm{~nm}$ using $\mathrm{NaNO}_{2}$ as a standard curve. Each treatment was carried out in three replicates.

\section{IL-1 $\beta$ ELISA kit assay}

Concentration of IL-1 $\beta$ in culture media was measured using human IL-1 $1 /$ IL-1F2 Immunoassay kit (R\&D Systems, MN, USA) according to the product datasheets.

\section{Immunofluorescence assay}

RAW264.7 cells were plated on a square glass coverslip at a concentration of $3 \times 10^{5}$ cells $/ \mathrm{mL}$ in a 6 -well plate. Cells were pretreated with CJE $(200 \mu \mathrm{g} / \mathrm{mL})$ for $1 \mathrm{~h}$, and LPS $(1 \mu \mathrm{g} / \mathrm{mL})$ was added for another $30 \mathrm{~min}$. Cells were harvested for fixing, permeating, and blocking as described in our previous study. Cells were incubated with the primary antibody of p65 (1:200) overnight at $4{ }^{\circ} \mathrm{C}$ and then incubated with the second antibody (m-IgGk BP-FITC 1:1000) for $2 \mathrm{~h}$ at room temperature. After staining the nuclei with DAPI, images were collected using super resolution confocal laser scanning microscope (magnification, $63 \times)$.

\section{Preparation of RAW264.7 cells protein extracts}

RAW264.7 cells were plated at a concentration of $1 \times 10^{6}$ cells $/ \mathrm{mL}$ in a 6 -well plate. The normal control group cells were treated with medium, and the LPS-treated group cells were stimulated by LPS $(1 \mu \mathrm{g} / \mathrm{mL})$ only. The co-treatment group cells were pre-treated with different concentrations of CJE (100 or $200 \mu \mathrm{g} / \mathrm{mL})$ for $1 \mathrm{~h}$, and then LPS $(1 \mu \mathrm{g} / \mathrm{mL})$ was added. All cells were incubated for $30 \mathrm{~min}$ or $18 \mathrm{~h}$ at $37^{\circ} \mathrm{C}$ in a $5 \% \mathrm{CO}_{2}$ and $95 \%$ air incubator. The cells were washed with ice-cold phosphatebuffered saline (PBS) three times and then lysed with 100 $\mu \mathrm{L}$ of whole protein cell lysis buffer $[5 \mathrm{M} \mathrm{NaCl}, 0.5 \mathrm{M}$ EDTA, 1 M Tris (PH 8.0), 10\% NP-40, 10\% sodium deoxycholate, and $10 \%$ SDS]. The tubes were placed on ice for $15 \mathrm{~min}$, vortexed every $5 \mathrm{~min}$, and then centrifuged at $13,000 \mathrm{rpm}$ for $15 \mathrm{~min}$. The supernatant containing the protein was collected and stored at $-80^{\circ} \mathrm{C}$ until analysis.

\section{Rat maintenance and surgery of acute reflux esophagitis}

Seven-week-old male Sprague-Dawley rats $(180 \pm 20 \mathrm{~g})$ were used according to the animal welfare recommendations of the Institutional Animal Care and Use Committee of Chonbuk National University Laboratory Animal Center in South Korea. Rats were kept in standard rat cages and supplied food and water ad libitum in a facility maintaining a $12 \mathrm{~h} \mathrm{light/dark} \mathrm{cycle} \mathrm{and} \mathrm{a} \mathrm{controlled} 21^{\circ} \mathrm{C}$ to $25^{\circ} \mathrm{C}$ temperature and $35-60 \%$ humidity environment. Rats were acclimated for one week under these conditions and subsequently divided into four groups $(n=8)$ 
randomly: normal group, RE control group, medication group, and positive control group. Rats were fasted for $18 \mathrm{~h}$ before surgery. Two $\mathrm{h}$ before surgery, the normal group rats did not receive oral administration, and the $\mathrm{RE}$ control group rats were orally administered saline; the medication group rats were orally administered CJE at a dose of $200 \mathrm{mg} / \mathrm{kg}$ body weight, and the positive control group rats were orally administered ranitidine at $40 \mathrm{mg} /$ $\mathrm{kg}$ body weight. The rats were anesthetized nasally. A $2 \mathrm{~cm}$ incision was made in the rats' abdomens to expose the stomach, and both the junction of the stomach and forestomach and the pylorus were ligated using a 3-0 silk thread. Care was taken to ensure that the vagus nerve remained intact $[17,18]$. All rats were sacrificed $4.5 \mathrm{~h}$ after the surgery. The stomach and esophagus were removed to determine the ratio of esophageal injury. The esophageal tissue was stored at $-80^{\circ} \mathrm{C}$ until analysis.

\section{Esophageal damage ratio}

The esophageal and gastric tissue was placed on paper and digitally photographed after esophageal mucus was washed away with $0.9 \%$ saline. The esophageal injury was analyzed using Image J software. The esophageal lesion index was calculated as follows: lesion index $(\%)=$ area of esophageal damage $\left(\mathrm{mm}^{2}\right) /$ total area of esophagus $\left.\left(\mathrm{mm}^{2}\right)\right] \times 100$.

\section{Esophageal histological study}

A 4-5 $\mathrm{mm}$ section of esophageal tissue was removed, placed in $4 \%$ NBF fixative, and fixed with paraffin. Slices were $5 \mu \mathrm{m}$ thick and stained with hematoxylin/eosin. Images were acquired with a Leica microscope at $10 \mathrm{X}$ magnification.

\section{Preparation of cytoplasmic and nuclear protein fractions from esophageal tissue}

The nuclear and cytoplasmic proteins of esophageal tissue were extracted according to our previous method [19]. In brief, esophageal tissues were homogenized in ice-cold lysis buffer containing $10 \mathrm{mM}$ HEPES, $10 \mathrm{mM}$ $\mathrm{KCl}, 2 \mathrm{mM} \mathrm{MgCl} 2,0.1 \mathrm{mM}$ EDTA, $1 \mathrm{mM} \mathrm{DTT}$, and protease inhibitor mixture solution. Samples were stained on ice for $30 \mathrm{~min}$. After centrifugation at 13,000 rpm for $2 \mathrm{~min}$ at $4{ }^{\circ} \mathrm{C}$, the supernatant with the cytoplasmic proteins was collected. The remaining pellet was re-suspended with extraction buffer containing $50 \mathrm{mM}$ HEPES, $50 \mathrm{mM} \mathrm{KCl}, 300 \mathrm{mM} \mathrm{NaCl}, 0.1 \mathrm{mM}$ EDTA, $1 \%$ (v/v) glycerol, $1 \mathrm{M}$ DTT, and protease inhibitor mixture solution. Following incubation on ice for $30 \mathrm{~min}$, the sample was centrifuged at $13,000 \mathrm{rpm}$ for $10 \mathrm{~min}$ at $4{ }^{\circ} \mathrm{C}$. The supernatant with the nuclear protein fraction was collected and stored at $-80{ }^{\circ} \mathrm{C}$ until analysis.

\section{Western blot analysis}

Equal amounts of quantitative proteins were separated by SDS-polyacrylamide gel electrophoresis (SDSPAGE) with different percentages and transferred to PVDF membranes. The membranes were blocked with $5 \%$ skim milk for $2 \mathrm{~h}$ at room temperature, washed with ice-cold PBS, and then incubated with primary antibodies $(1: 1000)$ overnight at $4{ }^{\circ} \mathrm{C}$. Finally, the membranes were treated with HRP-conjugated secondary antibodies $(1: 10,000)$ for $1.5 \mathrm{~h}$ with gentle shaking at room temperature. Bands were visualized using a Luminol reagent, a 1:1 ratio of solutions $A$ and $B$, and Bio-Rad image software (NY, USA).

\section{Statistical analysis}

All data are expressed as mean \pm standard deviation. One-way ANOVA followed by LSD multiple comparisons analyses were performed using SPSS $12.0 \mathrm{~K}$ (IBM Corporation, Chicago, IL, USA) for Windows. A $P$-value $<0.05$ indicated a significant difference.

\section{Results}

\section{Effect of CJE on DPPH and ABTS free radical scavenging} activity

DPPH and ABTS free radical scavenging assays are widely used to evaluate the anti-oxidative activity of medicinal plant extracts. Ascorbic acid is a natural antioxidant commonly used as a reference material. As shown in Fig. 1a, b, CJE eliminated 50\% of DPPH radicals at a concentration of $50 \mu \mathrm{g} / \mathrm{mL}$ and more than $70 \%$ of DPPH radicals at a concentration of $100 \mu \mathrm{g} / \mathrm{mL}$, similar to ascorbic acid $(20 \mu \mathrm{g} / \mathrm{mL})$. CJE eliminated $60 \%$ of ABTS radicals at a concentration of $200 \mu \mathrm{g} / \mathrm{mL}$, also similar to ascorbic acid $(40 \mu \mathrm{g} / \mathrm{mL})$.

\section{Effect of CJE on production of intracellular reactive oxygen species (ROS) in LPS-induced RAW264.7 cell}

ROS play an important role in cell signaling and maintaining homeostasis. However, excessive ROS caused by stimulation can induce tissue and cell structure damage. As shown in Fig. 1c, LPS stimulation increased the production of intracellular ROS compared with normal cells, while CJE treatment significantly inhibited the amount of ROS production dose-dependently.

\section{Effect of CJE on RAW264.7 cell viability and morphological change}

As shown in Fig. 2a, no cytotoxicity was observed at concentrations of 50,100 , and $200 \mu \mathrm{g} / \mathrm{mL}$ of CJE. As shown in Fig. 2b, cell morphological changes like shape change were observed in the LPS-induced group, and co-treatment with CJE reduced the morphological changes. The 

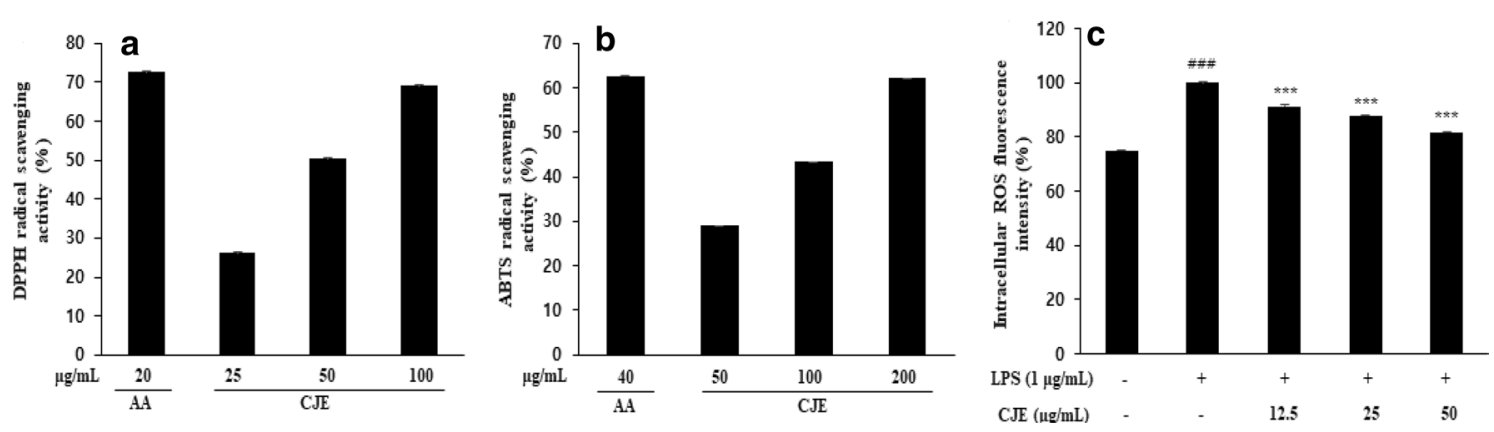

Fig. 1 DPPH a and ABTS $\mathbf{b}$ radical scavenging activity of CJE was measuredusing DPPH and ABTS radical scavenging assay. AA ascorbic acid was used as areference material. Fluorescence intensity of intracellular ROS $\mathbf{c}$ inLPS-induced RAW264.7 cell was measured by DCFH-DA fluorescent probe. ${ }^{\# \# \#} P<0.001$ vs. normal cells $s_{i}^{* * *} P<0.001$ vs. LPS-induced cells. Results are the mean \pm SD from three independent experiments
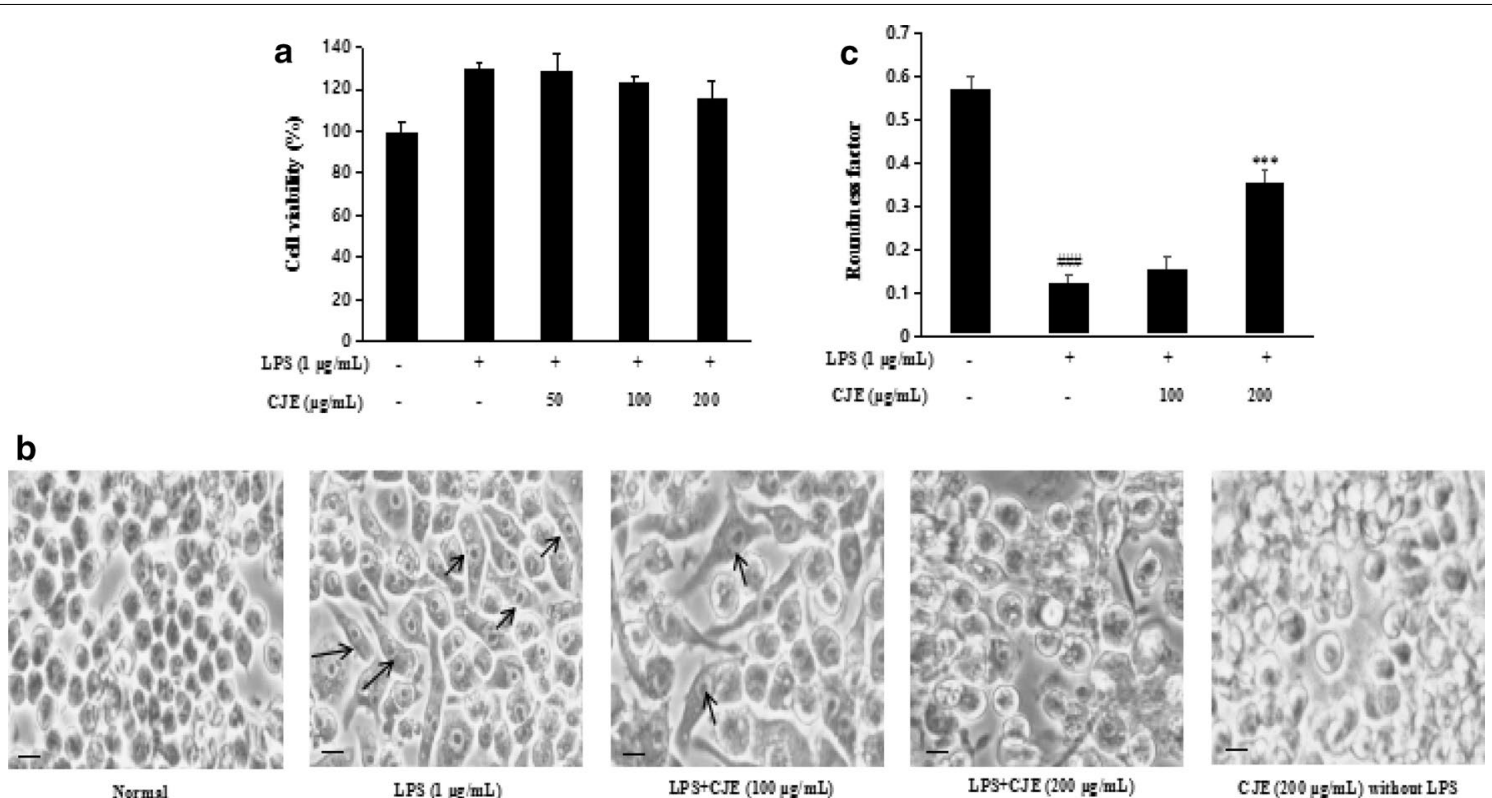

Fig. 2 Effect of CJE on cell viability a inLPS-induced RAW264.7 cell was checked using proliferation and cytotoxicityassay kit. Cell morphology $\mathbf{b}$ was observed by inverted microscope and cellmorphology quantitative calculation was using Image J program. ${ }^{\# \#} P<0.001$ vs. normal cells; ${ }^{* * *} P<0.001$ vs. LPS-induced cells. Results are the mean \pm SD from three independent experiments

quantitative result of cell morphology is shown in Fig. 2c. The roundness factor (RNF) is an important parameter for evaluating cell shape. The closer is the RNF value to 1 , the closer is the cell shape to a circle [20].

\section{Effect of CJE on NO production, IL-1 $\beta$ production, iNOS and TNF- $\alpha$ expression levels in LPS-stimulated RAW264.7 cells}

Nitric oxide (NO) is an important signaling molecule that transmits intracellular and intercellular signals and functions as a biological mediator, similar to neurotransmitters in the neuronal system, to protect the host against invading foreign pathogens [4]. Excessive production of
$\mathrm{NO}$ is regulated by iNOS, which induces inflammatory responses in macrophages. IL-1 $\beta$ and TNF- $\alpha$, important pro-inflammatory cytokines that are central regulators of inflammation, are secreted by several types of cells, such as macrophages and monocytes [21]. Cells were incubated with CJE at different concentrations and then stimulated with LPS $(1 \mu \mathrm{g} / \mathrm{mL})$ for another $18 \mathrm{~h}$. As shown in Fig. 3a, LPS caused an increase in NO production, while CJE pre-treatment significantly reduced NO production dose-dependently. The inhibition rate of NO production was greater than $50 \%$ at a CJE concentration of $200 \mu \mathrm{g} /$ $\mathrm{mL}$. LPS also increased the concentration of IL- $1 \beta$, and inhibition of IL- $1 \beta$ production was close to $50 \%$ with a 

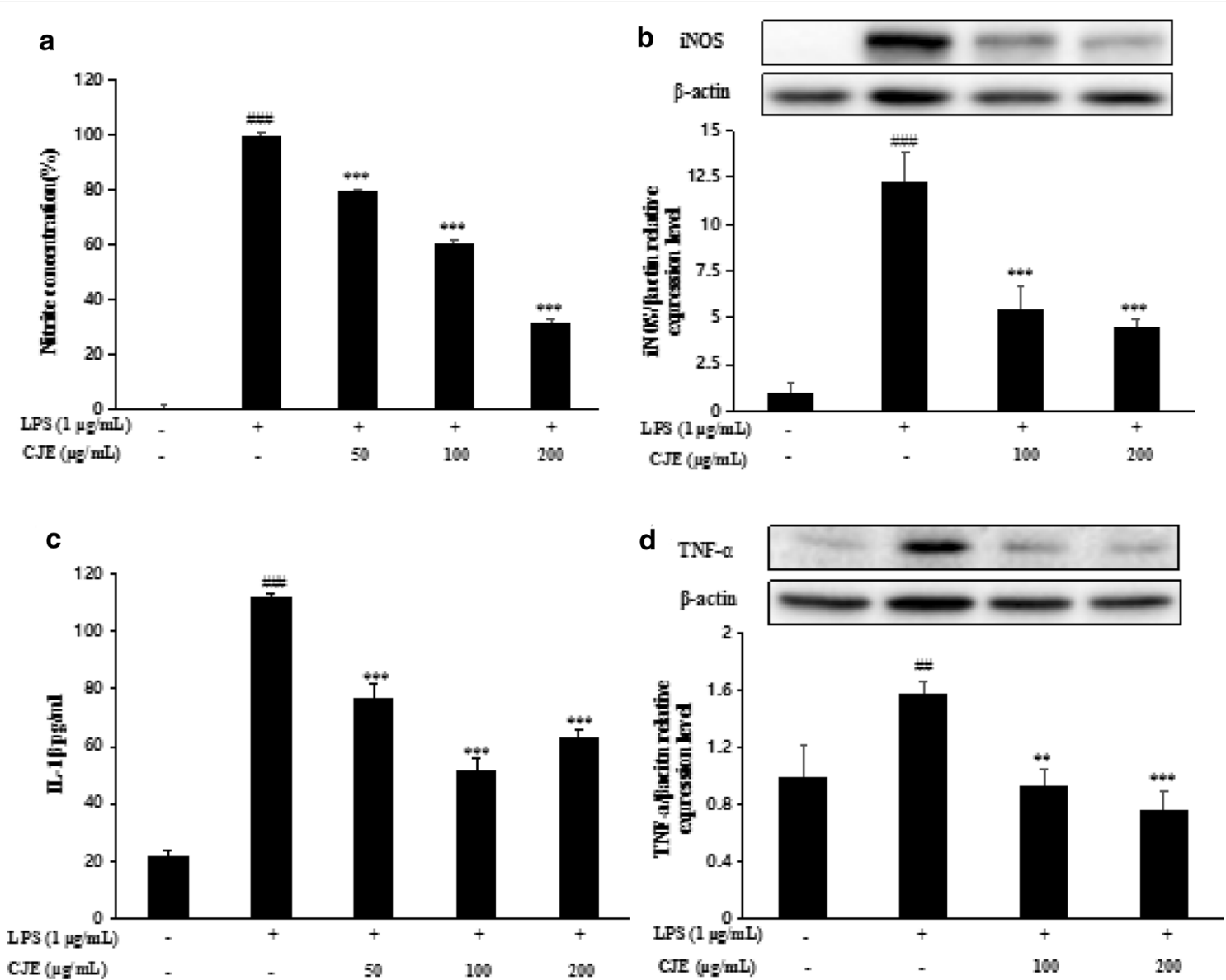

Fig. 3 Effect of CJE on nitrite production a,expression level of iNOS b, IL-1 $\beta$ production c and expression level ofTNF-a in LPS induced RAW264.7

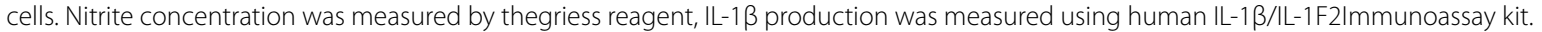
Expression level of iNOS and TNF-a was measured by westernblotting. ${ }^{\# \#} P<0.001,{ }^{\# \#} P<0.01$ vs. normal cells; ${ }^{* * *} P<0.001,{ }^{* * *} P<0.01$ vs. LPS-induced cells. Resultsare the mean \pm SD from three independent experiments

CJE concentration of $100 \mu \mathrm{g} / \mathrm{mL}$ (Fig. 3c). Furthermore, pretreatment with CJE at concentrations of 100 and $200 \mu \mathrm{g} / \mathrm{mL}$ clearly down-regulated the expression levels of iNOS (Fig. 3b) and TNF- $\alpha$ (Fig. 3d) induced by LPS.

\section{Effect of CJE on the phosphorylation of NF-KB and IKBa and NF-KB nuclear translocation in LPS-stimulated RAW264.7 cells}

Nuclear factor (NF)- $\mathrm{B}$ is an important regulator of inflammatory responses. The activity of NF- $\mathrm{BB}$ is regulated mainly by inhibitory proteins of the IkB family. Activated NF- $\kappa B$ translocate into the nucleus to further regulate the expression of inflammatory cytokines [22]. Cells were incubated with CJE at concentrations of 100 and $200 \mu \mathrm{g} / \mathrm{mL}$ and then stimulated with LPS $(1 \mu \mathrm{g} / \mathrm{mL})$ for another $30 \mathrm{~min}$. As shown in Fig. 4b, LPS stimulation induced nuclear transfer of NF-kB while CJE $(200 \mu \mathrm{g} /$ $\mathrm{mL})$ significantly inhibited this condition. In addition, phosphorylation of NF-kB and I $\mathrm{B} \alpha$ increased with LPS treatment but CJE pretreatment significantly suppressed their phosphorylation at a concentration of $200 \mu \mathrm{g} / \mathrm{mL}$ (Fig. 4a).

\section{Effect of CJE on the phosphorylation of JNK/p-38/MAPK in LPS-induced RAW264.7 cells}

Mitogen-activated protein kinase (MAPK) cascade pathways are involved in regulating the protein expression of some pro-inflammatory genes [23, 24]. Cells were incubated with CJE at concentrations of 100 and $200 \mu \mathrm{g} /$ $\mathrm{mL}$ for $1 \mathrm{~h}$ and then stimulated with LPS $(1 \mu \mathrm{g} / \mathrm{mL})$ for another $30 \mathrm{~min}$. As shown in Fig. 5, LPS activated JNK and p-38 expression; in contrast, CJE significantly decreased the expression levels of phosphorylated JNK and p-38 at a concentration of $200 \mu \mathrm{g} / \mathrm{mL}$.

\section{CJE suppressed esophageal damage in RE rats}

After ligation surgery, rat esophagi were stimulated by repeated reflux of gastric acid, which led 


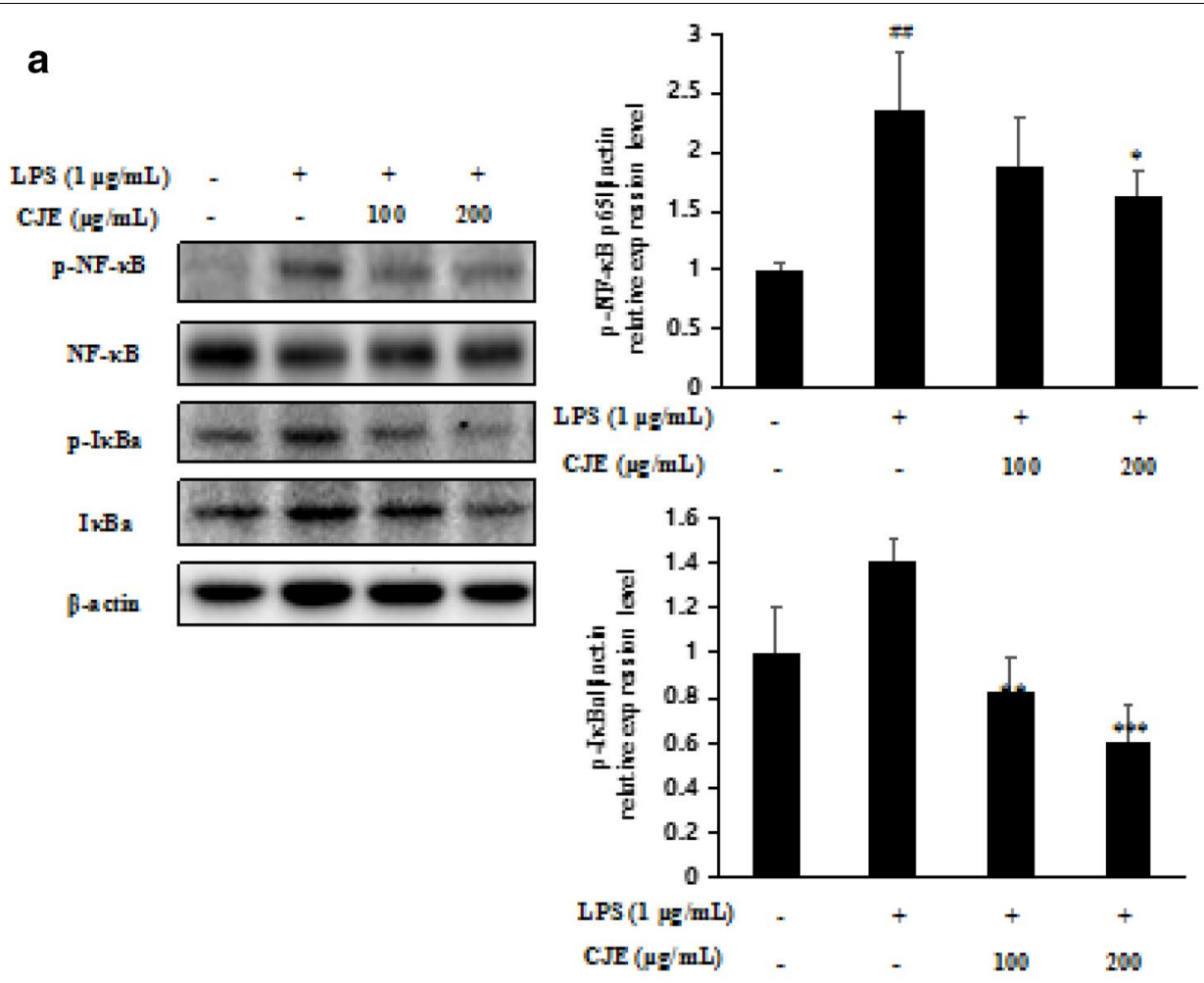

b

DAPI

$\mathrm{NF}-\mathbf{k B}$

Merge
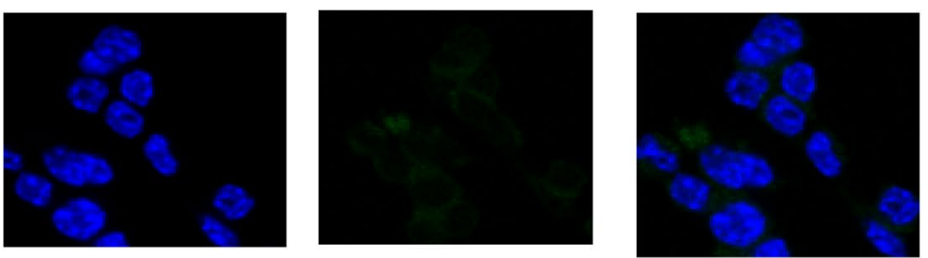

Normal
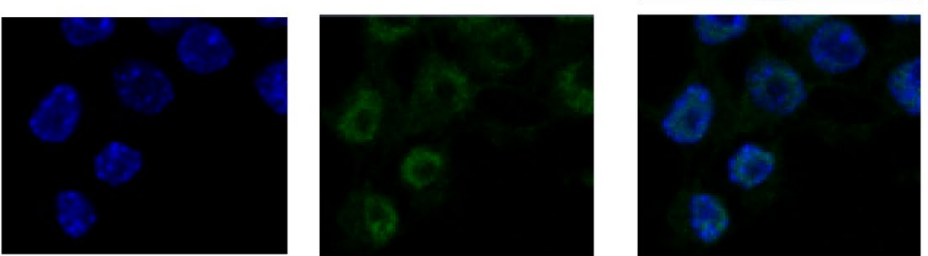

LPS (1 $\mu \mathrm{g} / \mathrm{mL})$
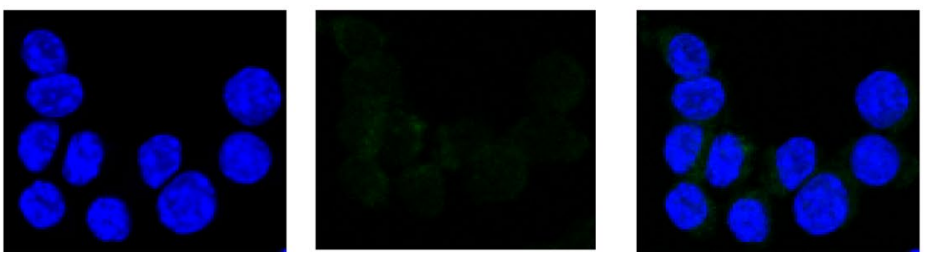

LPS + C JE 200

Fig. 4 Effect of CJE on phosphorylation level ofNF-KB, IKBa $\mathbf{a}$ and NF-KB nuclear translocation $\mathbf{b}$ inLPS-induced RAW264.7 cell was measured by western blotting andimmunofluorescence assay. ${ }^{\#} P<0.01,{ }^{\sharp} P<0.05$ vs. normal cells; ${ }^{* * *} P<0.001,{ }^{* *} P<0.01,{ }^{*} P<0.05$ vs. LPS-inducedcells. Results are the mean \pm SD from three independent experiments 


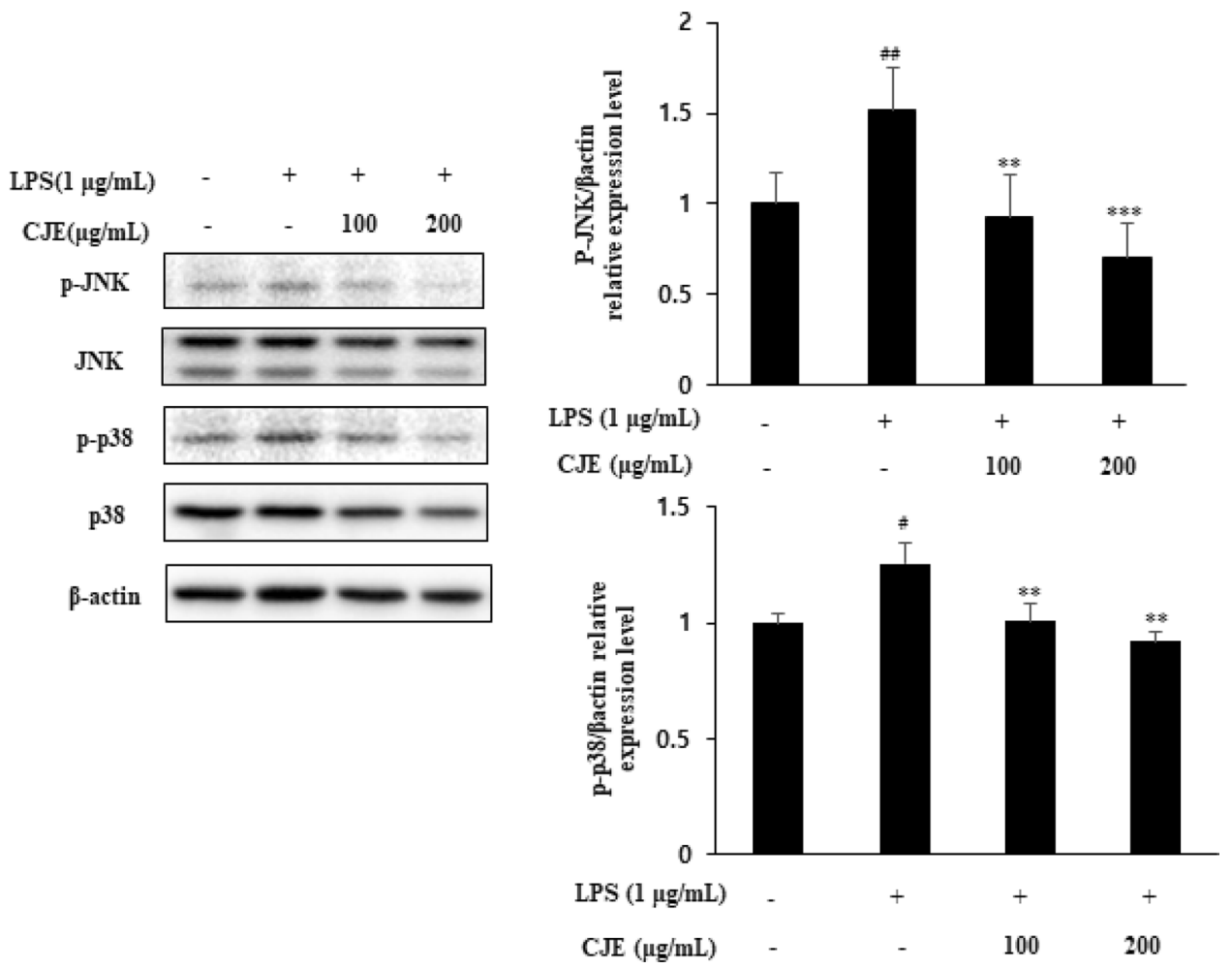

Fig. 5 Effect of CJE onphosphorylation level of JNKand p-38 in LPS-induced RAW264.7 cell was measured by western blotting. ${ }^{\# \#} P<0.01,{ }^{\#} P<0.05$ VS. normal cells; ${ }^{* * *} P<0.001,{ }^{* *} P<0.01$ vs. LPS-induced cells. Resultsare the mean \pm SD from three independent experiments

to tissue damage and inflammation. Unblemished, intact esophageal tissue was observed in the normal group, while large-scale black-red hemorrhagic lesions and erosion of esophageal tissue were observed in the RE control group (Fig. 6a). Oral administration of CJE $(200 \mathrm{mg} / \mathrm{kg})$ reduced esophageal tissue damage by $50 \%$ (Fig. $6 \mathrm{~b}$ ). Oral administration of the positive control ranitidine $(40 \mathrm{mg} / \mathrm{kg})$ reduced esophageal tissue damage by $70 \%$ compared with the RE control group.

\section{CJE attenuated histological changes in RE rats}

Intact mucosa, submucosa, and muscularis externa tissue were observed in the esophagi of normal group rats (Fig. 6c). In contrast, serious histological changes including complete exfoliation of the epithelial layer and sparse tissue structure in the submucosal and muscularis externa layer were observed in the esophagis of the RE control group rats. However, the degree of esophageal tissue histological changes in the medication group (oral administration of CJE $200 \mathrm{mg} / \mathrm{kg}$ ) and positive control group (oral administration of ranitidine $40 \mathrm{mg} / \mathrm{kg}$ ) was significantly improved.
CJE inhibited protein expression of COX-2, TNF- $\alpha$, and IL-1 $\beta$ in the esophagus

Increased expression of COX-2, TNF- $\alpha$, and IL- $1 \beta$ induced by repeated reflux of gastric acid was observed in the RE control group, while oral administration of CJE markedly inhibited the expression of these proteins, similar to the positive control group (ranitidine) (Fig. 7).

\section{CJE suppressed activation of NF-KB in the esophagus}

To investigate whether NF- $\mathrm{B} B$ was activated in the rat $\mathrm{RE}$ model, we evaluated the protein expression of phosphorylated NF- $\mathrm{KB}$ and the inhibitory protein I $k \alpha \alpha$. NF- $\kappa B$ and I $\mathrm{B} \alpha \alpha$ phosphorylation was markedly increased in the $\mathrm{RE}$ control group, indicating the activation of NF- $\kappa B$ and $I \kappa B \alpha$ by RE (Fig. 8). In contrast, the phosphorylation levels of NF- $\kappa B$ and $I \kappa B \alpha$ were significantly reduced by oral administration of CJE, similar to the effect of the standard drug ranitidine.

\section{Discussion}

Oxidative stress refers to a state caused by the imbalance between oxidative and reduction in the body. This imbalance can lead to excessive generation of ROS which is further induced inflammatory mediator and cytokines 


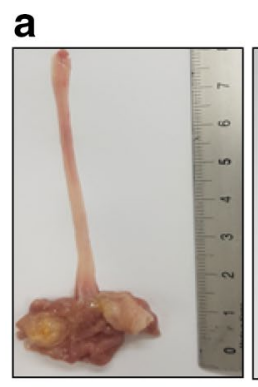

Normal

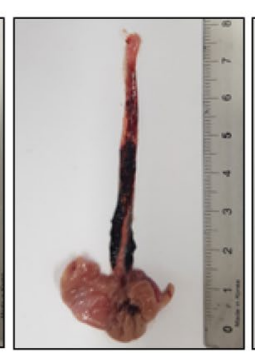

RE-control

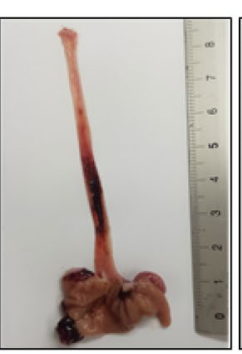

$\mathrm{RE}+\mathrm{CJE}-200$

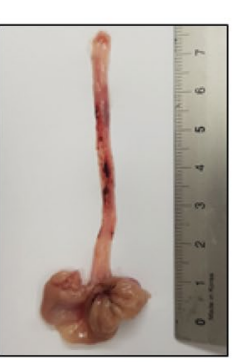

RE + Ranitidine 40

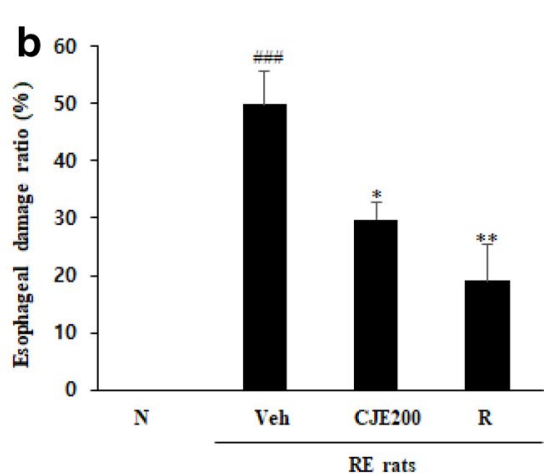

C

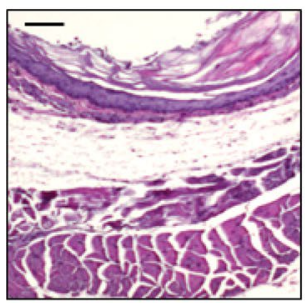

Normal

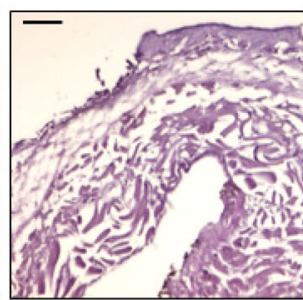

RE-control

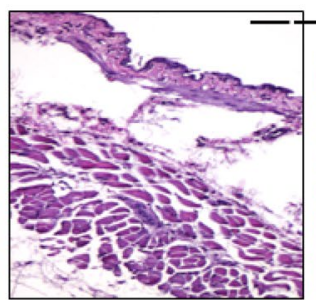

RE + CJE-200

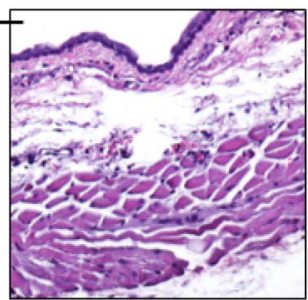

RE + Ranitidine $\mathbf{4 0}$

Fig. 6 Effectof CJE on esophageal tissue damage a, esophageal damage ratio $\mathbf{b}$ andhistological changes of the esophagus in each group (c). $\mathrm{N}$ - Normal rat, Veh -RE control rat, CJE 200 - RE rats pretreated with CJE $200 \mathrm{mg} / \mathrm{kg}$ and R - RE ratstreated with ranitidine $40 \mathrm{mg} / \mathrm{kg}$. Values are presented as the mean \pm standarddeviation. ${ }^{\# \#} P<0.001$ vs. normal rat, ${ }^{* *} P<0.01,{ }^{*} P<0.05$ vs. RE control rat
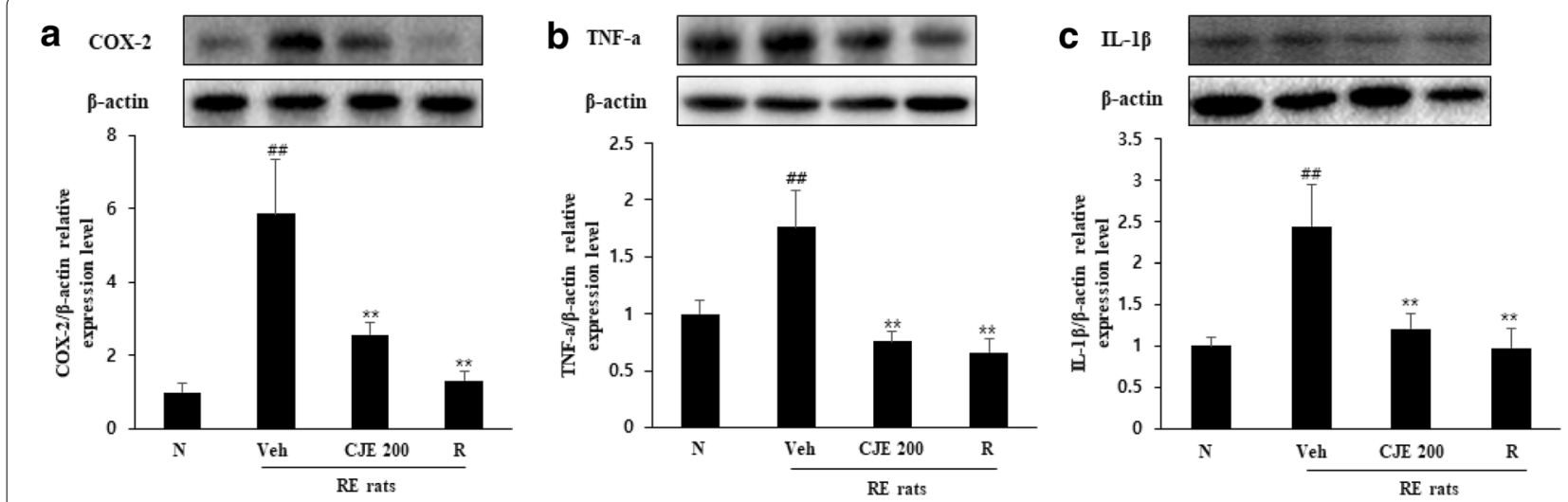

Fig. 7 Effectof CJE on protein expression levels of COX-2 (a), TNF-a (b) and IL-1 $\beta$ (c) inrats esophageal tissue. The protein levels of COX-2, TNF-a and IL-1 $\beta$ weredetermined by western blotting. $\mathrm{N}$ - Normal rat, Veh - RE control rat, CJE 200 -RE rats pretreated with CJE 200 mg/kg and R - RE rats treated with ranitidine $40 \mathrm{mg} / \mathrm{kg}$. The relative band intensity was measured as compared with $\beta$-actin.Values are presented as the mean \pm standard deviation. ${ }^{\#} P<0.01$ vs. normal rat, ${ }^{* *} P<0.01$ vs. RE-control rat

production, leading to aging and the occurrence and development of inflammation [25]. Therefore, scavenging free radicals in the body can inhibit the damage to body cells and tissues caused by excessive ROS, thereby inhibiting the further development of diseases. Plant extract have been shown to protect biological systems from oxidative stress caused by ROS by eliminating free radicals [26]. In the present study, we explored the anti-oxidant effects of CJE. Results show that CJE eliminated DPPH and ABTS free radicals and inhibited excessive production of ROS in LPS-induced RAW 264.7 cells.

LPS is an endotoxin, a component of the outer wall of the cell wall of gram-negative bacteria. It is composed of lipid A, core polysaccharide, and $\mathrm{O}$-antigen. The most significant indicator of cellular inflammation induced by LPS is the overproduction of inflammatory mediator NO [27]. When it acts on biological cells, it will show its effect through TLR4 in the cell membrane [28]. The TLR 

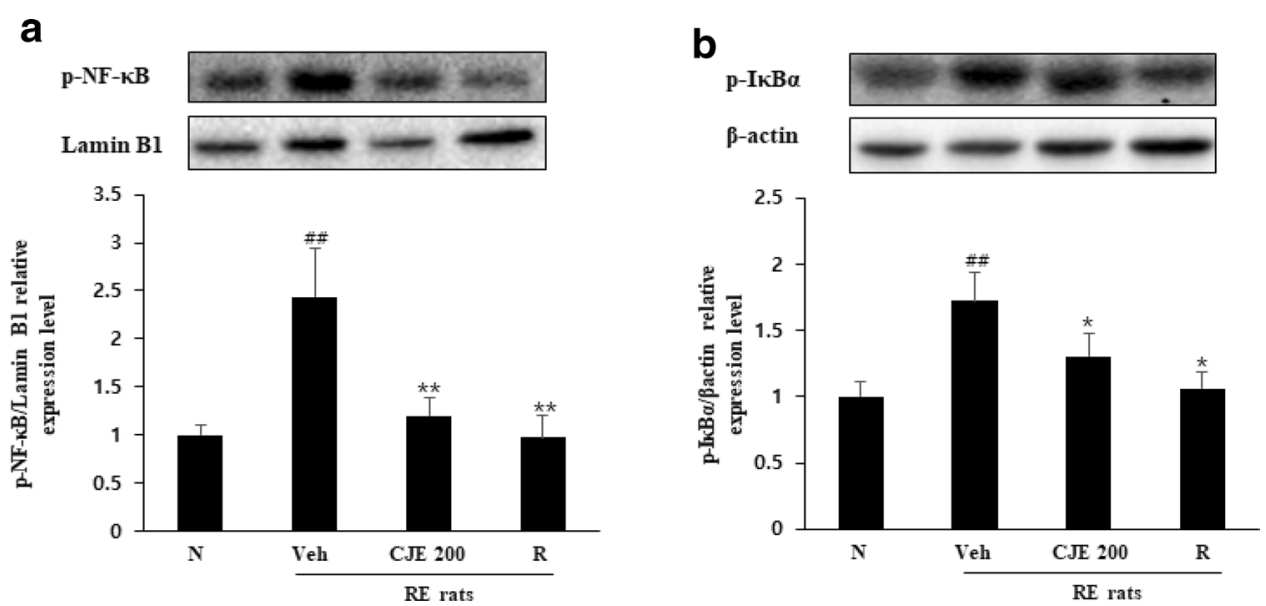

Fig. 8 Effectof CJE on protein expression levels of phosphorylated NF-KB (a) and IKBa (b) inrats esophageal tissue. The protein levels of p-NF-kB and $\mathrm{p}-\mathrm{I} \mathrm{KB}$ a weredetermined by Western blotting. The relative band intensity of $\mathrm{p}-\mathrm{NF}-\mathrm{KB}$ andp-IKBa were measured as compared with Lamin B1 and $\beta$-actin. N - Normal rat, Veh- RE control rat, CJE 200 - RE rats pretreated with CJE $200 \mathrm{mg} / \mathrm{kg}$ and R - RErats treated with ranitidine $40 \mathrm{mg} / \mathrm{kg}$. Values are presented as the mean \pm standard deviation. ${ }^{\# \#} P<0.01 \mathrm{vs}$. normal rat, ${ }^{* *} P<0.01,{ }^{*} P<0.05$ vs. RE-controlrat

family is related to the expression of inflammatory proteins (iNOS and COX-2), cytokines (TNF- $\alpha$ and IL-1 $\beta$ ) and plays an important role in natural immunity and inflammation [29]. The macrophage RAW264.7 inflammatory model induced by LPS is usually used to demonstrate the physiological activities of plant extracts or active substances. The degree of inflammatory response can be judged by the expression levels of inflammationrelated proteins and the secretion levels of inflammatory factors in cells [2].

The NF- $\mathrm{kB}$ signaling pathway has long been recognized as a classical pro-inflammatory pathway due to the role of activated NF- $\mathrm{KB}$ in the expression of inflammationrelated mediators and cytokines [30]. In the cytoplasm, the inhibitory protein $\mathrm{I} \kappa \mathrm{B} \alpha$ inactivates NF- $\mathrm{\kappa B}$ transcription factor by masking its nuclear localization signal. When cellular inflammation occurs, activated NF- $\mathrm{kB}$ enters the nucleus to bind to DNA and induce transcription of target genes such as iNOS, COX-2, TNF- $\alpha$ and IL-1 $\beta$. Furthermore, MAPK,a protein kinase, is an important transmitter of cell signals. It can be activated by different extracellular stimuli, such as cytokines and neurotransmitters, and regulates cell growth and differentiation [31]. It also regulates a variety of important cell physiological/pathological processes such as cell stress response to the environment and inflammation [31]. Activated MAPKs signaling pathway regulate the gene expression of inflammatory cytokines and proteins [32]. Therefore, inhibiting the activation of the NF-kB/MAPK signaling pathway can inhibit the expression of inflammation-related factors and control the initial stage of inflammation development to avoid deterioration. In the present study, results show that CJE inhibited production of NO and IL- $1 \beta$ in culture medium and protein expression levels of iNOS and TNF- $\alpha$ and down-regulated the activation levels of NF- $\kappa B$ and I $\kappa \mathrm{B} \alpha$ as well as JNK/p38/ MAPK phosphorylation. These results indicate that inhibition of the NF- $\mathrm{kB} / \mathrm{JNK} / \mathrm{p} 38 \mathrm{MAPK}$ signaling pathway activation may contribute to the anti-inflammatory activity of CJE.

$\mathrm{RE}$ is an inflammatory disease, the incidence of which has shown a significant increase from 2.5 to $7.8 \%$ in the past 10 years in some Asian countries, like as China and Korea [33]. RE patients endure different levels of distress such as heartburn, reflux, and sleep disorders, which seriously affect quality of patients life, apart from this, the long-term use of drugs brings considerable economic burden to the patients [34]. In the studies of RE, the acute rat RE animal model is widely used. By ligating the pylorus to prevent gastric contents from entering the duodenum and by ligating the forestomach to reduce stomach volume, gastric acid is more likely to reflux into the esophagus [35]. Gastric acid reflux leads to esophageal damage including inflammatory infiltration of esophageal cells and shedding of mucosal epithelial tissue [36]. In addition, the expression levels of inflammatory proteins and pro-inflammatory factors in the esophageal tissue vary depending on degree of esophageal injury and inflammation [37]. In the present study, we also used a rat RE model induced by ligation surgery to study the esophagus protective effect of CJE. Our research results show that gastric acid reflux lead to an increase in expression of inflammatory factors (COX-2, TNF- $\alpha$ and IL- $1 \beta)$ in the esophageal tissue, and at the same time up-regulated 
the phosphorylation levels of NF- $\kappa B$ and ІкB $\alpha$, which means that the NF- $k B$ signaling pathway may be the corresponding mechanism of RE. In addition, CJE oral gavage treatment significantly improved the degree of esophageal tissue damage while inhibiting the expression of COX-2, TNF- $\alpha$, IL-1 $\beta$ and phosphorylation levels of $\mathrm{NF}-\mathrm{\kappa} B$ and $\mathrm{I} \kappa \mathrm{B} \alpha$.

\section{Conclusions}

CJE effectively eliminates free radicals and reactive oxygen species, significantly inhibits the secretion and expression of various inflammatory factors, and at the same time down-regulates the activation level of NF- $k B / J N F / p 38 M A P K$ signaling pathway, which indicating that CJE can effectively inhibit LPS induced cell inflammation. CJE is a natural material with good antioxidant and anti-inflammatory activity. In addition, CJE significantly mitigated the rat's esophagus injury caused by gastric acid reflux, and also inhibited the expression of inflammatory factors in the esophagus tissue and the activation of NF-kB. Therefore, CJE has the possibility of being a candidate phytomedicine source for the treatment of RE.

\begin{abstract}
Abbreviations
RE: Reflux esophagitis; GERD: Gastroesophageal refluxdisease; CJE: C. japonica buds ethanol extract; DPPH: 1,1-diphenyl-2-picrylhydrazyl; ABTS: 2,2'-azinobis(3-ethylbenzothiazoline-6-sulfonic acid); ROS: Reactive oxygen species; NO: Nitric oxide; IL-1 $\beta$ : Interleukin-1 $\beta$; iNOS: Inducible nitric oxide synthase; TNF-a: Tumor necrosis factor-a; NF-KB: Nuclear factor K-light-chain-enhancer ofactivated $B$ cells; IKBa: Nuclear factor of kappa light polypeptide geneenhancer in B-cells inhibitor-a; JNK: c-Jun N-terminal kinase; p38/MAPK: p38 mitogenactivated protein kinases; LPS: Lipopolysaccharide; HEPE: 4-(2-hydroxyethyl)1-piperazineethanesulfonicacid; DCFH-DA: 2',7`-Dichlorofluorescin diacetate; DMSO: Dimethyl sulphoxide; DMEM: Dulbecco's modified eagle medium; FBS: Fetal bovine serum; DAPI: 4; 6-diamidino-2-phenylindole; EDTA: Ethylene diamine tetraacetic acid; SDS: Sodium dodecyl sulfate.
\end{abstract}

\section{Acknowledgements}

Not applicable.

\section{Authors' contributions}

$\mathrm{HHN}$ and $\mathrm{LN}$ are the co-first author, they made the same contribution in this study. All authors read and approved the finalmanuscript.

\section{Funding}

This research was carried out with the support of the National Research Foundation of Korea (NRF) (2020R111A3A04038157).

\section{Availability of data and materials}

The datasets used in this study are available from the corresponding author upon reasonable request.

\section{Ethics approval and consent to participate}

Seven-week-old male Sprague-Dawley rats were used according to the animal welfare recommendations of the Institutional Animal Care and Use Committee of Chonbuk National University Laboratory Animal Center in South Korea (IACUC; CBNU 2017-00079, date of approval, August 5, 2018).

\section{Consent for publication}

Not applicable.

\section{Competing interests}

The authors declare that they have no competing interests.

\section{Author details}

${ }^{1}$ Herbal Medicine Resources Research Center, Korea Institute of Oriental Medicine, 58245 Naju-si, Jeollanam-do, Republic of Korea. ${ }^{2}$ Agricultural College of Yanbian University, Jilin 133002 Yanji, People's Republic of China.

${ }^{3}$ Department of Crop Science \& Biotechnology, Chonbuk National University, 54896 Jeonju, Republic of Korea.

Received: 4 August 2020 Revised: 3 December 2020 Accepted: 11 December 2020

Published online: 07 January 2021

\section{References}

1. Mantovani A, Allavena P, Sica A, Balkwill F. Cancer-related inflammation. Nature. 2008;454:436-44.

2. Azizi G, Navabi SS, Al-Shukaili A, Seyedzadeh MH, Yazdani R, Mirshafiey A. The role of inflammatory mediators in the pathogenesis of Alzheimer's disease. Sultan Qaboos Univ Med J. 2015;15:305-16.

3. Hsu HY, Wen MH. Lipopolysaccharide-mediated reactive oxygen species and signal transduction in the regulation of interleukin-1 gene expression. J Biol Chem. 2002;277:22131-39.

4. Park EJ, Kim YM, Park SW, Kim HJ, Lee JH, Lee JH, et al. Induction of HO-1 through p38 MAPK/Nrf2 signaling pathway by ethanol extract of Inula helenium L. reduces inflammation in LPS-activated RAW 264.7 cells and CLP-induced septic mice. Food Chem Toxicol. 2013; 55:386-95.

5. Chawla A, Nguyen KD, Goh YP. Macrophage-mediated inflammation in metabolic disease. Nat Rev Immunol. 2011;1 1:738-49.

6. Hwang JH, Kim KJ, Ryu SJ, Lee BY. Caffeine prevents LPS-induced inflammatory responses in RAW264.7 cells and zebrafish. Chem Biol Interact. 2016;248:1-7.

7. Sandhu DS, Fass R. Current trends in the management of gastroesophageal reflux Disease. Gut Liver. 2018;12:7-16.

8. Wang YK, Hsu WH, Wang SS, Lu CY, Kuo FC, Su YC, et al. Current pharmacological management of gastroesophageal reflux disease. Gastroenterol Res Pract. 2013. https://doi.org/10.1155/2013/983653.

9. Colin-Jones DG. The role and limitations of $\mathrm{H}_{2}$-receptor antagonists in the treatment of gastro-oesophageal reflux disease. Aliment Pharmacol Ther. 1995;9:9-14.

10. Matsukura K, Hirose D, Kagami M, Osono T, Yamaoka Y. Geographical distributions of Rhytismataceous fungi on Camellia japonica leaf litter in Japan. Fungal Ecol. 2017;26:37-44.

11. Zhang YF, Tao QA. The research progress for Camellia japonica L. J Med Phar Chi Min. 2012;18:41-4.

12. Lee HS, Choi JH, Cui L, Li Y, Yang JM, Yun JJ, et al. Anti-Inflammatory and anti-oxidative effects of Camellia japonica on human corneal epithelial cells and experimental dry eye: in vivo and in vitro study. Invest Ophthalmol Vis Sci. 2017;58:1196-207.

13. Piao MJ, Yoo ES, Koh YS, Kang HK, Kim J, Kim YJ, et al. Antioxidant effects of the ethanol extract from flower of Camellia japonica via scavenging of reactive oxygen species and induction of antioxidant enzymes. Int J Mol Sci. 2011;12:2618-30.

14. Lee HH, Paudel KR, Jeong J, Wi AJ, Park WS, Kim DW, et al. Antiatherogenic effect of Camellia japonica fruit extract in high fat diet-fed rats. Evid Based Complement Alternat Med. 2016;2016:9679867.

15. Liyana-Pathirana C, Shahidi F. Antioxidant activity of commercial soft and hard wheat (Triticum aestivum L.) as affected by gastric $\mathrm{pH}$ conditions. J Agric Food Chem. 2005;53:2433-40.

16. Jing LL, Ma HP, Fan PC, Gao RM, Jia ZP. Antioxidant potential, total phenolic and total flavonoid contents of Rhododendron anthopogonoides and its protective effect on hypoxia-induced injury in $\mathrm{PC}_{12}$ cells. BMC Complement Altern Med. 2015. https://doi.org/10.1186/s1290 6-015-0820-3.

17. Gaia Filho EV, Goldenberg A, Costa HO. Experimental model of gastroesophageal reflux in rats. Acta Cir Bras. 2005:20:437-44.

18. Wang RH, Qu YQ, Chen X, Li GD, Xing JY. Establishment of reflux esophagitis models in rats. J ZheJiang Univ (Med Sci). 2009;38:297-304. 
19. Nan L, Nam HH, Choo BK, Park JC, Kim DG, Lee JH, et al. An Ethanolic Extract of Allium hookeri Root Alleviates Reflux Esophagitis and Modulates NF-ðB Signaling. Evid Based Complement Alternat Med. 2018. https://doi. org/10.1155/2018/1834681

20. Yu HY, Lim KP, Xiong SJ, Tan LP, Shim W. Functional Morphometric Analysis in Cellular Behaviors: Shape and Size Matter. Adv Healthcare Mater. 2013;2:1188-97.

21. Esposito E, Cuzzocrea S. TNF-Alpha as a Therapeutic target in inflammatory diseases, ischemia- reperfusion injury and trauma. Curr Med Chem. 2009;16:3152-67.

22. Rahman A, Fabeha F. Blocking NF-kB an inflammatory issue. Proc Am Thorac Soc. 2011:8:497-503.

23. Berghe WV, Plaisance S, Boone E, Bosscher KD, Schmitz L, Fiers W, et al. p38 and extracellular signal-regulated kinase mitogen-activated protein kinase pathways are required for nuclear factor-KB p65 transactivation mediated by tumor necrosis factor. J Biol Chem. 1998;273:3285-90.

24. Kaminska B. MAPK signaling pathways as molecular targets for antiinflammatory therapy from molecular mechanisms to therapeutic benefits. Biochim Biophys Acta. 2005;1754:253 - 62 .

25. Hussain T, Tan B, Yin B, Yin Y, Blachier F, Tossou MCB, et al. Oxidative Stress and Inflammation: What Polyphenols Can Do for Us? Oxid Med Cell Longev. 2016. https://doi.org/10.1155/2016/7432797.

26. Lee JH. Anti-Oxidant and Anti-Inflammatory Effects of Diospyros kaki Thumb Leaves Extracts. Kor J Aesther Cosmetol. 2014;12:719-24.

27. Chun SC, Jee SY, Lee SG, Park SJ, Lee JR, Kim SC. Anti-Inflammatory Activity of the Methanol Extract of Moutan Cortex in LPS-Activated Raw264.7 Cells. Evid Based Complement Alternat Med. 2007;4:327 - 33.

28. Wang SX, Cao M, Xu SH. Effect of luteolin on inflammatory responses in RAW264.7 macrophages activated with LPS and IFN-y. J Funct Foods. 2017;32:123 - 30 .

29. Lu XG, Min L, Wei JL, Gou HX, Bao ZJ, Wang JF, Wang Z, Huang YZ, An BC. Heliangin inhibited lipopolysaccharide-induced inflammation through signaling NF-KB pathway on LPS-induced RAW 264.7 cells. Biomed Pharmacother. 2017;88:102-8.

30. Moynagh PN. The NF-kB pathway. J Cell Sci. 2005;118:4389-92.
31. Oliveira RG, Campos Castilho GR, André Luiz C, Fábio M, Oliveira Martins DT. Dilodendron bipinnatum Radlk. inhibits pro-inflammatory mediators through the induction of MKP-1 and the down-regulation of MAPKp38/ JNK/NF-KB pathways and COX-2 in LPS-activated RAW 264.7 cells. J Ethnopharmacol. 2017;202:127-37.

32. Sun LD, Wang F, Dai F, Wang YH, Lin D, Zhou B. Development and mechanism investigation of a new Piper longumine derivative as a potent anti-inflammatory agent. Biochem Pharmacol. 2015;95:156-69.

33. El-Serag HB, Sweet S, Winchester CC, Dent J. Update on the epidemiology of gastro-oesophageal reflux disease: a systematic review. Gut. 2014;63:871-80.

34. Katz PO, Gerson LB, Vela MF. Guidelines for the diagnosis and management of gastroesophageal reflux disease. Am J Gastroenterol. 2013:108:308-28.

35. Jabria MA, Tounsi HF, Rtibi K, Marzouki La, Sakly M, Sebai H. Ameliorative and antioxidant effects of myrtle berry seed (Myrtus communis) extract during reflux-induced esophagitis in rats. Pharm Biol. 2016;25:1-11.

36. Kwon OJ, Choo BK, Lee JY, Kim MY, Shin SH, Seo Bl, et al. Protective effect of Rhei Rhizoma on reflux sophagitis in rats via Nrf2-mediated inhibition of NF-KB signaling pathway. BMC Complement Altern Med. 2016;16:26748627.

37. Pratibha S, Neetu S, Shibani S, Gautam P. Ameliorative effects of Panax quinquefolium on experimentally induced reflux oesophagitis in rats. Indian J Med Res. 2012;135:407-13.

\section{Publisher's Note}

Springer Nature remains neutral with regard to jurisdictional claims in published maps and institutional affiliations.
Ready to submit your research? Choose BMC and benefit from:

- fast, convenient online submission

- thorough peer review by experienced researchers in your field

- rapid publication on acceptance

- support for research data, including large and complex data types

- gold Open Access which fosters wider collaboration and increased citations

- maximum visibility for your research: over $100 \mathrm{M}$ website views per year

At $\mathrm{BMC}$, research is always in progress.

Learn more biomedcentral.com/submissions 